\title{
Uniaxial Heat Balance Model of the Solar Collector
}

\author{
K.A. Minakova, R.V. Zaitsev \\ National Technical University "Kharkiv Polytechnic Institute», 2, Kyrpychova St., 61002 Kharkiv, Ukraine
}

(Received 27 July 2021; revised manuscript received 20 October 2021; published online 25 October 2021)

\begin{abstract}
The paper considers photovoltaic (PV) systems, which are one of the most promising systems of renewable energy sources. The electricity produced by PV panels has great potential, but also has technological shortcomings that do not allow obtaining maximum efficiency. The aim of our study is to reduce technological shortcomings, which will increase the service life of PV systems and the amount of electricity received. The obtained model allows considering the technical parameters that take into account the heat loss and thermal resistance of the absorber plate. The results of the calculations performed coincide with the experimental data. The main aim of the proposed research is to consider a method for increasing the efficiency and lifetime of PV systems. This article briefly presents theoretical methods for increasing the efficiency of such systems, as well as increasing the service life, by simulating the cooling parameters of the absorber surface of such systems and tracking the maximum power. Modeling and the obtained theoretical model will allow in the future to select the most suitable technical solutions for the maximum energy output of PV systems for various design solutions.
\end{abstract}

Keywords: Photovoltaic systems, Solar energy, PV/T panels, Thermal conductivity, Temperature gradient, Solar thermal collector, Heat transfer.

DOI: 10.21272/jnep.13(5).05020

PACS numbers: 84.60. $-\mathrm{h}, 61.43 . \mathrm{Bn}$

\section{INTRODUCTION}

Photovoltaic (PV) systems, which convert solar energy into electricity, are promising systems among renewable energy sources. The electricity produced by PV panels has great potential, but at present, there are technological shortcomings that prevent them from increasing their efficiency. Moreover, eliminating these shortcomings can increase the service life of PV systems and the total amount of electricity produced.

The efficiency of modern PV cells (SC cells) currently ranges from 10 to $38 \%$ under standard conditions. The efficiency of PV panels is less than that of the PV cells used to create them. Thus, one way to increase efficiency is to find new suitable design solutions. An example of optimization of PV panels is the creation of PV/T panels [1,2]. This can be achieved by improving processes and models of heat balance [3, 4], the results of optimization research and methods are given in this article.

In earlier works [5-7], only options for heat removal from the tube along its surface were considered without losses when passing through the heat absorber plate that is a kind of heat absorber (absorber on which the tube is installed) and heat loss of the adsorbing surface.

\section{ADVANCED MODEL}

The heat sink absorber usually consists of round tubes connected to a flat absorber plate. The plate absorbs heat that enters the solar cell when exposed to sunlight and transfers it to the coolant circulating in the tubes [8]. The absorber and tubes are made of materials with high thermal conductivity (copper, aluminum) to optimize heat transfer to the liquid and reduce losses. Fig. 1 shows a cross section of the absorber.

The minimum temperature $\left(T_{p}\right)$ in the absorber is observed over the cooling tube. The maximum temperature is observed in the middle between the tubes $(x=0)$, that is, at the same distance from the tubes. The temperature gradient at this point is zero, and the temperature profile is symmetric. If the gradient is zero, then according to Fourier's law, there is no heat transfer at this point. Based on this, we can assume that the absorber plate is a normal edge of the radiator at $x=0$ and length $(W-D) / 2$ (Fig. 2).

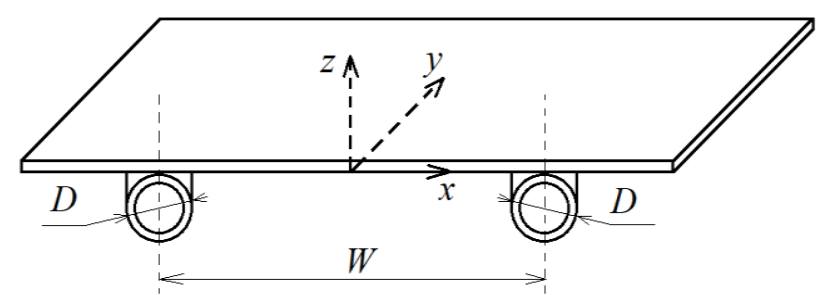

Fig. 1 - Absorber of the solar thermal collector

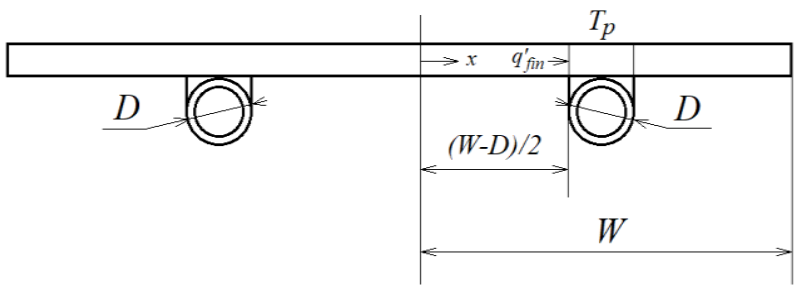

Fig. 2 - Temperature distribution in the absorber along the $x$-axis

Assume that the material of the absorber plate is thin and has a high thermal conductivity, and then the temperature above the tube can be considered as homogeneous at $T_{p}$. To simplify the analysis and evaluate heat transfer only in the $x$ direction [9-11], we suppose that there is no temperature gradient in the $y$ direction (along the tube). Under these conditions, the absorbing section between the middle $(x=0)$ and the surface above the tube $(x=(W-D) / 2)$ can be considered as a classical problem (Fig. 3). 


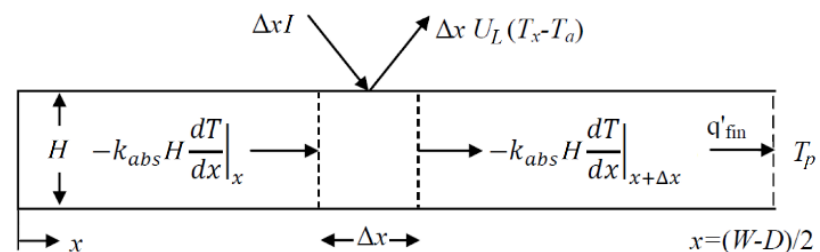

Fig. 3 - Heat balance in any part of the absorber

To analyze the configuration of the reduced areas, we apply the law of heat balance of a unit area $[12,13]$ (steady-state energy balance of an element) and obtain the following equation:

$$
\begin{gathered}
\Delta x I-\Delta x U_{L}\left(T_{x}-T_{a}\right)+\left(-\left.k_{a b s} H \frac{d T}{d x}\right|_{x}\right)- \\
-\left(-\left.k_{a b s} H \frac{d T}{d x}\right|_{x+\Delta x}\right)=0,
\end{gathered}
$$

where $I$ is the absorbed thermal energy $\left(\mathrm{W} / \mathrm{m}^{2}\right), H$ is the collector plate thickness $(\mathrm{m}), U_{L}$ is the loss factor $\left(\mathrm{W} / \mathrm{m}^{2} \cdot \mathrm{K}\right), k_{a b s}$ is the thermal conductivity of the absorber material $(\mathrm{W} / \mathrm{m} \cdot \mathrm{K}), T_{a}$ is the ambient temperature, $T_{x}$ is the temperature of the absorber at the point $x, q_{\text {fin }}^{\prime}$ is the heat transferred in the $x$ direction at $x=(W-D) / 2$ per unit length of the tube $(\mathrm{W} / \mathrm{m})$.

Calculating the above equation with respect to $\Delta x$ and finding the limit when $\Delta x$ approaches to $0[14,15]$, equation (1) can be reduced to the following form:

$$
\frac{d^{2} T}{d x^{2}}=\frac{U_{L}}{k_{a b s} H}\left(T_{x}-T_{a}-\frac{I}{U_{L}}\right) .
$$

As discussed earlier, if we do not take into account the heat transfer at $x=0$ and temperature $T_{p}$ above the tubes is constant [16], the following boundary conditions can be specified:

$$
\begin{gathered}
\left.\frac{d T}{d x}\right|_{x=0}=0,\left.T\right|_{x=(W-D) / 2}=T_{p}, \\
m^{2}=\frac{U_{L}}{k_{a b s} H} \\
\Psi=\left(T_{x}-T_{a}-\frac{I}{U_{L}}\right) .
\end{gathered}
$$

Equation (2) is simplified to:

$$
\frac{d^{2} \Psi}{d x^{2}}-m^{2} \Psi=0 .
$$

The marginal requirements of expression (3) are transformed as

$$
\left.\frac{d \Psi}{d x}\right|_{x=0}=0,\left.\quad \Psi\right|_{x=(W-D) / 2}=T_{p}-T_{a}-\frac{I}{U_{L}} .
$$

Expression (5) is a second-order linear differential equation. His general solution:

$$
\Psi=C_{1} \operatorname{sh} m x+C_{2} \operatorname{ch} m x .
$$

Applying the first boundary condition, we find

$$
\left.\frac{d \Psi}{d x}\right|_{x=0}=C_{1} \operatorname{sh} m x+\left.C_{2} \operatorname{ch} m x\right|_{x=0}=C_{1} m=0 .
$$

From the first boundary condition $m \neq 0$, therefore $C_{1}=n$, we obtain

$$
\left.\Psi\right|_{x=(W-D) / 2}=T_{p}-T_{a}-\frac{I}{U_{L}}=C_{2} \operatorname{ch}(m(W-D) / 2),
$$

$$
C_{2}=\frac{T_{p}-T_{a}-\frac{I}{U_{L}}}{\operatorname{ch}(m(W-D) / 2)}
$$

From relations (5) and (8) we obtain

$$
\begin{gathered}
\frac{T_{x}-T_{a}-\frac{I}{U_{L}}}{T_{p}-T_{a}-\frac{I}{U_{L}}}=\frac{\operatorname{ch}(m x)}{\operatorname{ch}(m(W-D) / 2)}, \\
T_{x}=T_{a}+\frac{I}{U_{L}}+\left(T_{p}-T_{a}-\frac{I}{U_{L}}\right) \frac{\operatorname{ch}(m x)}{\operatorname{ch}(m(W-D) / 2)} .
\end{gathered}
$$

Equation (13) allows us to calculate the temperature distribution in the absorber plate (Fig. 2) [17].

Heat $q_{\text {fin }}^{\prime}$, which is transferred to the collector area above the tube at $x=(W-D) / 2$, can be calculated from equation (13) using Fourier's law [18, 19]:

$$
\begin{gathered}
q_{\text {fin }}^{\prime}=-\left.k_{a b s} H \frac{d T}{d x}\right|_{x=\frac{W-D}{2}}=-k_{a b s} H\left(T_{\mathrm{p}}-T_{a}-\frac{I}{U_{L}}\right) \times \\
\times\left. m \frac{\operatorname{sh}(m x)}{\operatorname{ch}\left(\frac{m(W-D)}{2}\right)}\right|_{x=\frac{W-D}{2}}= \\
=-k_{a b s} H\left(T_{\mathrm{p}}-T_{a}-\frac{I}{U_{L}}\right) m \frac{\operatorname{sh}\left(\frac{m(W-D)}{2}\right)}{\operatorname{ch}\left(\frac{m(W-D)}{2}\right)}, \\
q_{\text {fin }}^{\prime}=\frac{k_{a b s} H}{U_{L}} m\left(I-U_{L}\left(T_{p}-T_{a}\right)\right) \operatorname{th}(m(W-D) / 2) .(15)
\end{gathered}
$$

Assuming that $m^{2}=\frac{U_{L}}{k_{\alpha b s} H}$, we obtain

$q_{f i n}^{\prime}=\frac{(W-D)}{2}\left(I-U_{L}\left(T_{p}-T_{a}\right)\right) \frac{\text { th }(m(W-D) / 2)}{(m(W-D) / 2)}$.

Relation (16) can be used to calculate the heat transferred to the area of the collector above the tube, when $x=(W-D) / 2$, on one side of the tube [20].

Let us define $F$ as the efficiency of the edge, i.e.

$$
F=\frac{\operatorname{th}(m(W-D) / 2)}{(m(W-D) / 2)},
$$

and substitute $F$ into (16)

$$
q_{\text {fin }}^{\prime}=\frac{(W-D)}{2}\left(I-U_{L}\left(T_{p}-T_{a}\right)\right) F .
$$

Equation (18) is the equation of the efficiency of the edge $(F)$. The efficiency of the edge is the ratio of the heat entering the area above the tube $\left(q_{\text {fin }}^{\prime}\right)$ to the heat obtained at a constant temperature $T_{p}$. This ratio simplifies the calculations and allows you to calculate the useful energy using a single temperature $T_{p}$.

If the heat transferred from the adsorber is known, it is possible to calculate the heat transferred to the coolant from both edges of the absorber.

Useful heat $q_{u}^{\prime}$ is the heat that is transferred from the absorber plate to the liquid inside the tube. $q_{u}^{\prime}$ can be obtained from the energy balance for the element shown in Fig. 4 [21]:

$$
\begin{gathered}
2 q_{f i n}^{\prime}+D I-D\left(I-U_{L}\left(T_{p}-T_{a}\right)\right)-q_{u}^{\prime}=0, \\
q_{\iota \iota}^{\prime}=((W-D) F+D)\left(I-U_{L}\left(T_{p}-T_{a}\right)\right) .
\end{gathered}
$$

In real conditions, the temperature $T_{p}$ is unknown; therefore, it is necessary to calculate the efficiency depending on the temperature of the liquid, which is 
known. Heat efficiency is the ratio of heat transferred from the area above the tube to the liquid coolant. If the communication resistance $R_{p}$ is known, then $q_{u}^{\prime}$ can be written relative to the temperature of the liquid $T_{f}$.

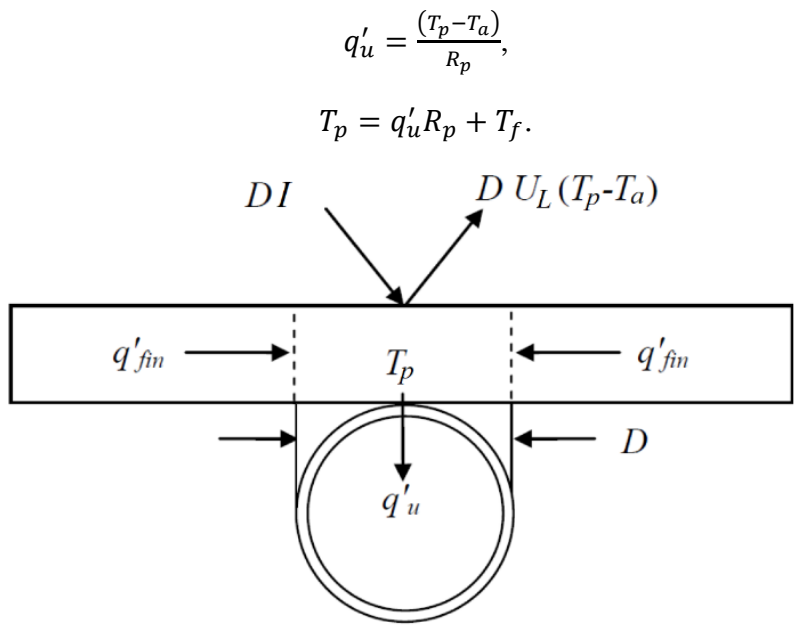

Fig. 4 - Heat balance of the absorber area above the tube with the coolant

Communication resistance $R_{p}$ is the thermal resistance between the absorber plate on the tube and the liquid (associated with the technological type of connection of the tube with the absorber) [22-24]. The first term takes into account the heat transfer between the inner side of the tube and the liquid and also takes into account the inner diameter of the tube. The second term takes into account the heat transfer from the plate above the tube (the size of the contact is equal to the outer diameter of the tube). Communication resistance can be written in the following form (inverted into heat transfer):

$$
R_{p}=\frac{1}{h_{w} \pi(D-2 B)}+\frac{H}{k_{w} D},
$$

where $h_{w}$ is the heat transfer coefficient between the inside of the tube and the liquid $\left(\mathrm{W} / \mathrm{m}^{2} \cdot \mathrm{K}\right), H$ is the thickness of the layer on the tube $(\mathrm{m}), k_{w}$ is the thermal conductivity of the site $(\mathrm{W} / \mathrm{m} \cdot \mathrm{K}), B$ is the tube wall thickness (m).

Substituting (20) into equation (19), we obtain

$$
q_{u}^{\prime}=\frac{1}{\frac{1}{U_{L}((W-D) F+D)}+R_{p}}\left(I-U_{L}\left(T_{f}-T_{a}\right)\right)
$$

and

$$
F^{\prime}=\frac{1 / U_{L}}{W\left[\frac{1}{U_{L}((W-D) F+D)}+R_{p}\right]} .
$$

Given the above expressions, we get:

$$
q_{u}^{\prime}=W F^{\prime}\left(I-U_{L}\left(T_{f}-T_{a}\right)\right)
$$

Relation (22) is the collector efficiency equation $\left(F^{\prime}\right)$. The efficiency of the collector is the ratio of the actual energy transferred to the liquid $\left(q_{u}^{\prime}\right)$ [25] to the energy obtained at a constant temperature of the absorber and temperature of the liquid $T_{f}$. This ratio simplifies the calculations and allows you to calculate the useful energy using one unknown temperature $T_{f}$. Coefficient $F^{\prime}$ is similar to the efficiency of the edge $F$, because it connects the heat transfer characteristics with the coolant temperature.

Equation (23) can be used to calculate the useful energy collected per unit length of the tube in the $y$ direction.

\section{TESTING THE HEAT BALANCE MODEL OF THE SOLAR COLLECTOR}

Based on the results of mathematical analysis in the mathematical package PTC MathCAD, a corresponding model was built. Using this model, the maximum achievable values of the temperature difference when using the classical reservoir layer were determined (Fig. 5). The following input data were used for the calculation: $T_{a}=298{ }^{\circ} \mathrm{C}, I=1000 \mathrm{~W} / \mathrm{m}^{2}, T_{f}=283^{\circ} \mathrm{C}$, $W=0.125 \mathrm{~m}, H=0.0005 \mathrm{~m}, D=0.12 \mathrm{~m}$, and the corresponding parameters of thermal conductivity of copper. From the figure you can see that in the classical solution of the collector absorber plate, the temperature difference reaches $7.15^{\circ} \mathrm{C}$, which is quite important for using such a solution in PV/T systems.

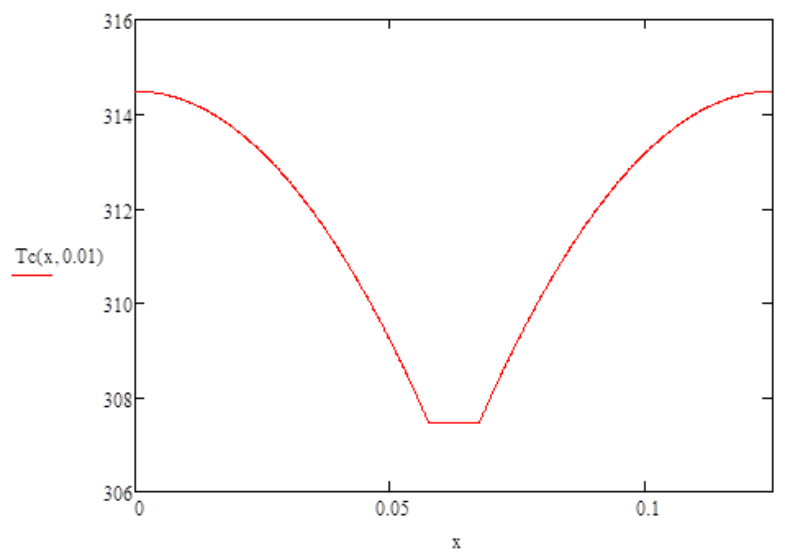

Fig. 5-Temperature distribution on the collector absorber plate according to Fig. 2

The use of the developed model for solving optimization problems will allow, at the design stage of solar collectors and PV/T systems, to choose their optimal parameters to achieve maximum efficiency and minimum cost. For example, to select the parameters of the absorber for use in PV/T systems, it is necessary to change its geometric parameters. Fig. 6 shows an example of modeling a change in the diameter of the tube with the coolant, from which you can see a significant effect of the tube diameter on the temperature difference along the surface of the absorber.

From Fig. 6, it can be seen that the developed model can be used to solve optimization problems in the design of solar collectors and PV/T systems with further development to multiparameter problems, and the results correspond to the experimental results.

\section{CONCLUSIONS}

Based on the results of the analysis of heat exchange processes in the plates of the absorber of heat collectors, a mathematical model of the operation of the specified absorber is developed. The proposed model 


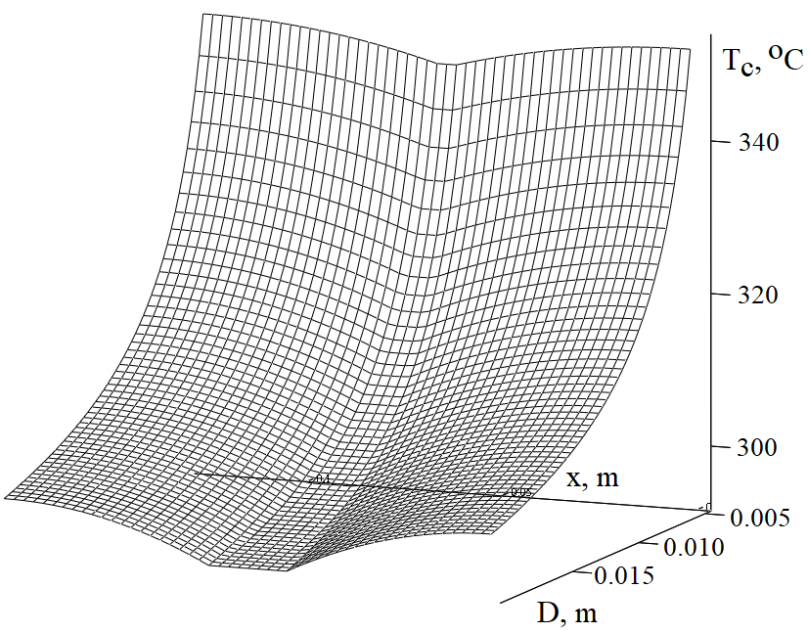

Fig. 6 - Results of modeling the influence of the diameter of the tube with the coolant on the temperature distribution on the absorber surface

\section{REFERENCES}

1. X. Yang, L. Sun, Y. Yuan, Renew. Energy 119, 152 (2018).

2. D. Das, P. Kalita, O. Roy, Renew. Sustain. Energy Rev. 84, 111 (2018).

3. N. Khordehgah, A. Żabnieńska-Góra, H. Jouhara, Chemengineering 4 No 2, 22 (2020).

4. R.V. Zaitsev, M.V. Kirirchenko, G.S. Khrypunov, J. NanoElectron. Phys. 11 No 4, 04029 (2019).

5. K. Minakova, R. Zaitsev, J. Nano- Electron. Phys. 12 No 4, 04028 (2020)

6. R.V. Zaitsev, M.V. Kirichenko, G.S. Khrypunov, J. NanoElectron. Phys. 10 No 6, 06017 (2018).

7. R.V. Zaitsev, M.V. Kirichenko, G.S. Khrpunov, 2017 IEEE International Young Scientists Forum on Applied Physics and Engineering, 112 (Ukraine, Kharkiv, 2015).

8. M. Ghadiri, M. Sardarabadi, M. Pasandideh-fard, Energy Conversion and Management 103, 468 (2015).

9. A. Kelin, O. Larin, R. Naryzhna, O. Trubayev, O. Vodka, M. Shapovalova Integrated Computer Technologies in Mechanical Engineering 1113, 271 (2020).

10. V. Nerubatskyi, O. Plakhtii, D. Hordiienko, S. Mykhalkiv, V. Ravluyk, Eastern-European Journal of Enterprise Technologies 1(8), 6 (2021).

11. V.V. Eremenko, V.A. Sirenko, I.A. Gospodarev, E.S. Syrkin, S.B. Feodosyev, I.S. Bondar, K.A. Minakova, A. Feher, J. Phys.: Conference Series 969 No 1, 012021 (2018).

12. V.V. Eremenko, V.A. Sirenko, I.A. Gospodarev, A.V. Dolbin, I.A. Gospodarev, E.S. Syrkin, S.B. Feodosyeva, I.S. Bondar, K.A. Minakova, Low Temp. Phys. 42 No 5, 401 (2016).

13. H. Liang, F. Wang, L. Yang, Z. Cheng, Y. Shuai, H. Tan, Renew. Sustain. Energy Rev. 141, 110785 (2021). allows taking into account additional parameters that have not been considered before, namely heat loss and thermal resistance in the absorber plate.

The offered basic relations allow solving optimization problems for creating optimal designs of absorber plates for solar collectors and highly effective PV/T systems. The developed physico-mathematical model, which describes the operation of solar collectors and $\mathrm{PV} / \mathrm{T}$ systems, makes it possible to analyze and take into account the design parameters to achieve maximum efficiency.

Based on the results of the calculation, the model was tested in the mathematical package PTC MathCAD and its compliance with experimental data was confirmed. Further development of the model provides an opportunity to create multiparameter tasks to create highly efficient PV/T systems.
14. M.V. Kirichenko, R.V. Zaitsev, A.L. Ivanov, D.S. Lobotenko, International Young Scientists Forum on Applied Physics, art. PECCS-5 (Ukraine, Dnipropetrovsk, 2015).

15. V.P. Nerubatskyi, O.A. Plakhtii, D.V. Tugay, et. al., Scientific Bulletin of National Mining University 177 No 1, 61 (2021).

16. E.V. Manzhelii, S.B. Feodosyev, I.A. Gospodarev, I.A. Gospodarev, E.S. Syrkin, K.A. Minakova, Low Temp. Phys. 41 No 7, 557 (2015).

17. O. Plakhtii, V. Nerubatskyi, Ya. Scherbak, et. al., 2020 IEEE KhPI Week on Advanced Technology, 165 (Ukraine, Kharkiv, 2020).

18. M.R. Saffarian, M. Moravej, M.H. Doranehgard, Renew. Energy 146, 2316 (2020).

19. M. Simoncelli, N. Marzari, A. Cepellotti, Phys. Rev. X 10, 011019 (2020)

20. O. Rubanenko, O. Miroshnyk, S. Shevchenko, et. al., 2020 IEEE KhPI Week on Advanced Technology, 52 (Ukraine, Kharkiv, 2020).

21. H.P. Singh, A. Jain, A. Singh, S. Arora, Appl. Thermal Eng. 156, 692 (2019).

22. V.V. Eremenko, V.A. Sirenko, I.A. Gospodarev, S.B. Feodosyeva, I.S. Bondar, S.S. Saxena, A. Feher, K.A. Minakova, Low Temp. Phys. 42 No 2, 134 (2016).

23. D. Zhang, H. Tao, M. Wang, Z. Sun, C. Jiang, Appl. Thermal Eng. 118, 113 (2017).

24. E. Sokol, V. Zamaruiev, S. Kryvosheev, et. al., 2017 IEEE First Ukraine Conference on Electrical and Computer Engineering, 432 (Ukraine, Kiyv, 2017).

25. M. Carmona, M. Palacio, Sol. Energy 177, 620 (2019).

\title{
Одновісна модель теплового балансу сонячного колектора
}

\author{
К.О. Мінакова, Р.В. Зайцев
}

Національний технічний університет "Харківський політехнічний інститут", вул. Кирпичова 2, 61002 Харків, Украӥна

В роботі розглядаються фотоелектричні (PV) системи, які є одними з найперспективніших систем відновлюваних джерел енергії. Електроенергія, що виробляеться PV панелями, мае великий потенціал, але й технологічні недоліки, які не дають отримати максимальну ефективність. Цель нашого дослідження - зменшення технологічних недоліків, що дозволить збільшити термін служби PV систем та кількість отриманої електроенергії. Отримана модель дозволяе розглядати технічні параметри, які 
враховують втрати теплової енергії та тепловий опір пластини абсорбера. Результати розрахунків, що були проведені, співпадають з експериментальним даним. Основною метою запропонованого дослідження є розгляд методу підвищення ефективності та терміну служби PV систем. У статті коротко представлені теоретичні методи підвищення ефективності таких систем, а також збільшення терміну служби шляхом моделювання параметрів охолодження поверхні поглинача таких систем та відстеження максимальної потужності. Моделювання та отримана теоретична модель дозволять у майбутньому вибрати найбільш підходящі технічні рішення для максимального виходу енергії PV систем для різних конструктивних рішень.

Ключові слова: Фотоелектричні системи, Сонячна енергія, PV/T панелі, Теплопровідність, Температурний градіент, Сонячний тепловий колектор, Теплообмін. 